\title{
Pharmacognostic Evaluation and HPTLC Finger Printing of Rhizome of Chlorophytum borivilianum Sant. and F. from Nepal
}

\author{
Kopila Adhikari ${ }^{1,}{ }^{*},{ }^{\prime}$ N Anuradha' ${ }^{1}$, N. Prabhu Suchitra ${ }^{2}$
}

\section{Kopila Adhikari ${ }^{1 *}$ \\ KN Anuradha ${ }^{1}$}

N. Prabhu Suchitra ${ }^{2}$

'Department of Dravyaguna,

SDM College of Ayurveda and Hospital, Hassan, Karnataka, INDIA.

2Pharmacognosy and Phytochemistry, SDM Research Center for Ayurveda and Allied Science, Kuthpady, Udupi, Karnataka, INDIA.

\section{Correspondence}

Adhikari Kopila

Department of Dravyaguna, SDM College of Ayurveda and Hospital, Hassan, Karnataka, INDIA.

Phone no: +917829555533

Email: drkopiladg@gmail.com

\section{History}

- Submission Date: 10-04-2018.

- Review completed: 22-05-2018;

- Accepted Date: 11-07-2018

DOI : 10.5530/pj.2018.5.163

Article Available online

http://www.phcogj.com/v10/i5

\section{Copyright}

(C) 2018 Phcog.Net. This is an openaccess article distributed under the terms of the Creative Commons Attribution 4.0 International license.

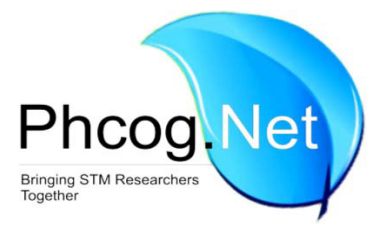

\begin{abstract}
Introduction: Chlorophytum borivilianum Sant. and F.; commonly known as Shveta Musali from the family Liliaceae is a perennial herb. It is used in Ayurveda, Traditional Chinese Medicine, Unani and in folklore practice as an aphrodisiac herb. Present study depicts pharmacognostic features of Chlorophytum borivilianum Sant. and F. collected from Nepal. Methods: Macromicroscopic analyses, physico-chemical studies and HPTLC finger printing of rhizomes of Chlorophytum borivilianum Sant. and F. were carried out according to pharmacopoeial procedures. Results: Microscopic analysis has shown presence of epidermis, cork, cortex, collenchymatous cells, starch grains, cluster crystals of calcium oxalate, idioblast, phloem, vascular bundles, pitted xylem parenchyma, sclereids, stone cells, fragment of epiblema, and acicular needles. Preliminary phytochemical analysis revealed presence of alkaloid, carbohydrate, carboxylic acid, resins and saponins. TLC photo-documentation revealed presence of many phyto-constituents with different Rf values and HPTLC densitometric scan of the plates showed numerous bands under short UV, long UV and $620 \mathrm{~nm}$ (after derivatisation). Conclusion: Chlorophytum borivilianum Sant. and F. was evaluated for its pharmacognostic features and HPTLC. These specific identities will be useful in identification and authentication of the raw drug.
\end{abstract}

Key words: Chlorophytum borivilianum, Pharmacognostic, Phytochemical, Shveta Musali, Quality Control.

\section{INTRODUCTION}

Chlorophytum includes nearly 300 species which are distributed throughout tropical and subtropical parts of the world. Seventeen species of Chlorophytum is recorded in India. ${ }^{1}$ Among them Chlorophytum borivilianum Sant. and F. is having highest saponin content which is responsible for its therapeutic utilities. ${ }^{2}$ It was first reported in India in 1954 and reached rare status in nature due to over exploitation. ${ }^{3}$ C. arundinaceum Baker, C. laxum R.Br., C. tuberosum Baker, C. orchidastrum Hook.f., p.p. non Lindl. are used as adulterant and substitutes. ${ }^{4}$ C. borivilianum is commercially cultivated and commonly used by pharmaceuticals. ${ }^{5}$ Chlorophytum borivilianum Sant. and F., also known as Shveta Musali, from the family Liliaceae, is a perennial herb, $10-35 \mathrm{~cm}$ in height; rhizome elongated, cylindrical, fleshy. Leaves are basal, linear-lanceolate and membranous with short petioles. White flowers with six petals, small, black seeds enclosed in flowering boles. ${ }^{6-8}$ It is used in Ayurveda, Traditional Chinese Medicine, Unani and in folklore practice as an aphrodisiac herb. It's rhizome is Shukrala, Rasayana, Vrisya, Balya, Brimhana, Madhura, Tikta, Snigdha,
Sheeta, and Laghu. ${ }^{4,9,10}$ It has shown spermatogenic, aphrodisiac, immune-modulatory, anti-diabetic, antioxidant, anti-stress, anti-microbial, anti-aging, antitumor and anti-inflammatory activities. ${ }^{11-15}$ Saponins (borivilianosides E-H), flavonoids, proteins, carbohydrate, phenolics, triterpenoids, tannis, sucrose, glucose, fructose, galactose, mannose and xylose have been reported from C. borivilianum. . $^{-3,15-16}$

\section{MATERIALS AND METHODS}

\section{Plant material}

Fresh rhizomes were collected from Chitwan District, Nepal in the month of November - December. The plant material was authenticated at Department of Dravyaguna, SDM College of Ayurveda Hassan, Karnataka and the voucher specimen was deposited in the respective herbarium for future reference (SDMCAH-DG/2017/14). The rhizomes were cleaned and shade dried. The dried rhizomes were coarsely powdered and used for macroscopic, microscopic characterization, phyto-chemical analysis and HPTLC.

Cite this article: Kopila A, Anuradha KN, Prabhu Suchitra N. Pharmacognostic Evaluation and HPTLC Finger Printing of Rhizome of Chlorophytum borivilianum Sant. and F. from Nepal. Pharmacogn J. 2018;10(5):963-8. 


\section{Organoleptic and Macroscopic Evaluation}

Fresh and dried rhizomes along with the powder were evaluated for their organoleptic and macroscopic features i.e. size, shape, color, odor, taste, texture and specific botanical characters were evaluated as per the standard procedure ${ }^{17}$ The external features of the test samples were documented using Canon IXUS digital camera.

\section{Microscopic evaluation}

Transverse section of rhizome: Sample was preserved in fixative solution. The fixative used was FAA (Formalin-5ml + Acetic acid-5ml + $70 \%$ Ethyl alcohol-90ml). The materials were left in FAA for more than $48 \mathrm{~h}^{18-19}$ The preserved specimens were cut into thin transverse section using a sharp blade and the sections were stained with safranin. The slides were also stained with iodine in potassium iodide for detection of starch. Transverse sections were photographed using Zeiss AXIO trinocular microscope attached with Zeiss Axio Cam camera under bright field light. Magnifications of the figures are indicated by the scale-bars.

\section{Powder microscopy}

Pinch of powder of rhizome previously sieved was put on the slide and mounted in glycerin. Powder characters are observed under the Zeiss AXIO trinocular microscope attached with Zeiss Axio Cam camera under bright field light.

\section{Physico-chemical analysis}

Physico-chemical parameters viz. loss on drying at $105^{\circ} \mathrm{C}$, total ash, acid insoluble ash, water soluble ash, ethanol and water soluble extractive values were evaluated using standard methods. ${ }^{20}$

\section{Preliminary phyto-chemical screening}

Ethanolic extract of C. borivilianum Sant. and F. was subjected to qualitative evaluation for the presence or absence different groups of phytoconstituents such as alkaloids, flavonoids, saponins, carbohydrates, carboxylic acid, coumarins, phenol, quinine, resins, steroid, tannin, terpenoid, and amino acids. ${ }^{20}$ Detail of phyto-chemical evaluation is illustrated in Table 3.

\section{HPTLC finger printing}

One gm of powdered sample of Chlorophytum borivilianum Sant. and F. was suspended in $10.0 \mathrm{ml}$ of alcohol (99.9\%) with intermittent shaking for the first few hours and kept for $24 \mathrm{~h}$ at room temperature followed by filtration, made up to $10.0 \mathrm{ml}$ with ethanol; $8 \mu \mathrm{l}$ of the above extract was applied on a pre-coated silica gel F254 on aluminum plates to a band width of $7 \mathrm{~mm}$ using Linomat 5 TLC applicator. The plate was developed in Toluene: Ethyl acetate (7.0: 3.0). The developed plates were visualized in short UV, long UV and then derivatised with vanillin sulphuric acid and scanned under UV 254nm, 366nm and 620nm. Retention factor $(R f)$, color of the spots and densitometric scan were recorded using CAMAG Scanner $4 .{ }^{21-22}$

\section{RESULTS}

\section{Organoleptic and macroscopic observations}

Results obtained from organoleptic and macroscopic observations of fresh rhizome and powder are illustrated in the Table 1.

\section{Microscopic evaluation}

Microscopic evaluation of transverse section of rhizome of Chlorophytum borivilianum Sant. and F. revealed the presence of epidermis, cork, starch grains, idioblast cells, outer cortex, xylem, phloem, radial vascular bundle, collenchyma cells, single layered endodermis, stellar region, pith, and numerous cluster crystals. The details of the microscopic evaluation of transverse section of rhizome are presented in Figure 1. Microscopic
Table 1: Organoleptic and Macroscopic Evaluation of Chlorophytum borivilianum Sant. and F.

\begin{tabular}{lll}
\hline Observations & Rhizome & Powder \\
\hline Size & $5-12 \mathrm{~cm}$ long, $1.5-2 \mathrm{~cm}$ diameter & NA \\
Shape & Elongated & NA \\
Color & Whitish & Brownish \\
Odor & Not characteristics & Not characteristics \\
Taste & Madhura, Tikta, Mucilagenous & $\begin{array}{l}\text { Madhura, Tikta, } \\
\text { Mucilagenous }\end{array}$ \\
Texture & & $\begin{array}{l}\text { Smooth } \\
\end{array}$ \\
\hline
\end{tabular}

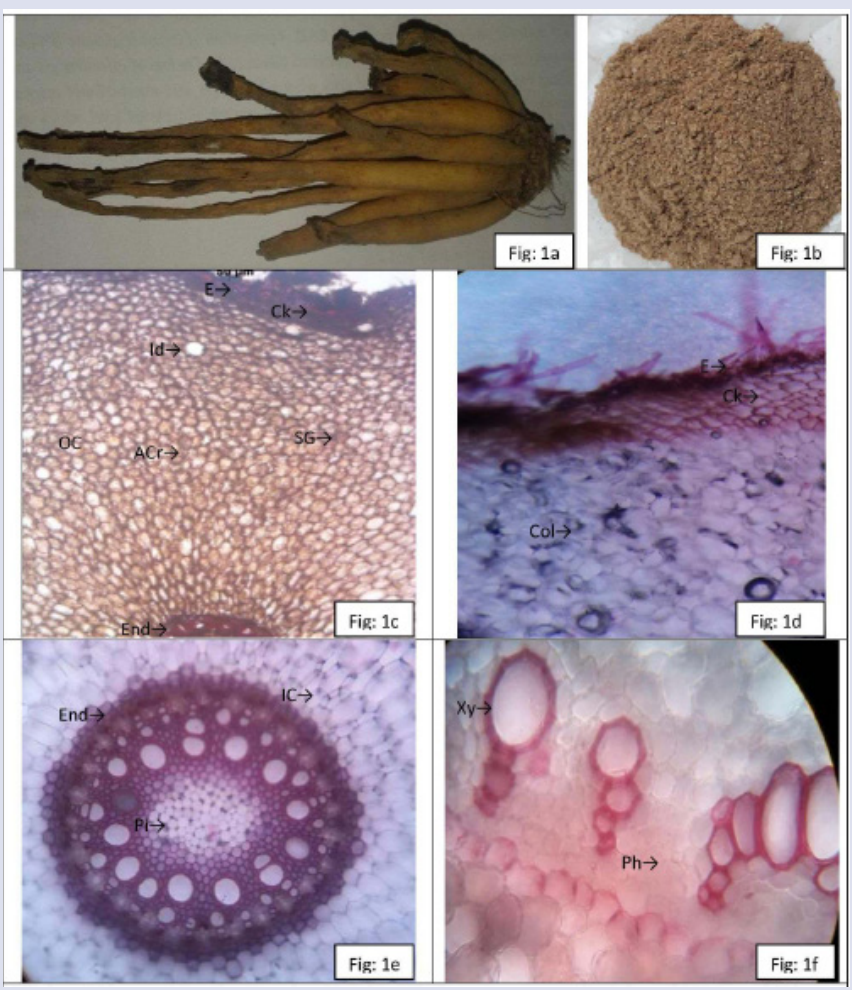

Figure 1: Macro-microscopic features of Rhizome of Chlorophytum borivilianum Sant. and $\mathrm{F}$.

Fig. la - Rhi/ome; Fig. Ib - Powder; Fig. Ic - TS through outer region; Fig. Id - Enlarged TS through outer region; Fig. le - TS through inner region; Fig. If - Enlarged xylem and phloem; E - Epidermis; Ck - Cork; Id - Idioblast; OC Outer cortex; ACr - Acicular crystal; SG - Starch grain: Col - Collenchyma: End - Endodermis; IC - Inner cortex; Pi - Pith; Xy - Xylem; Ph - Phloem.

evaluation of powder of rhizome of Chlorophytum borivilianum Sant. and F. revealed the presence of starch grains, pitted xylem parenchyma, vessels, cork, sclereids, stone cells, fragment of epiblema, acicular needles. The details of the powder microscopy of rhizome are presented in Figure 2.

\section{Physico-chemical analysis}

Physico-chemical characters were evaluated and the results obtained are illustrated in Table 2. 


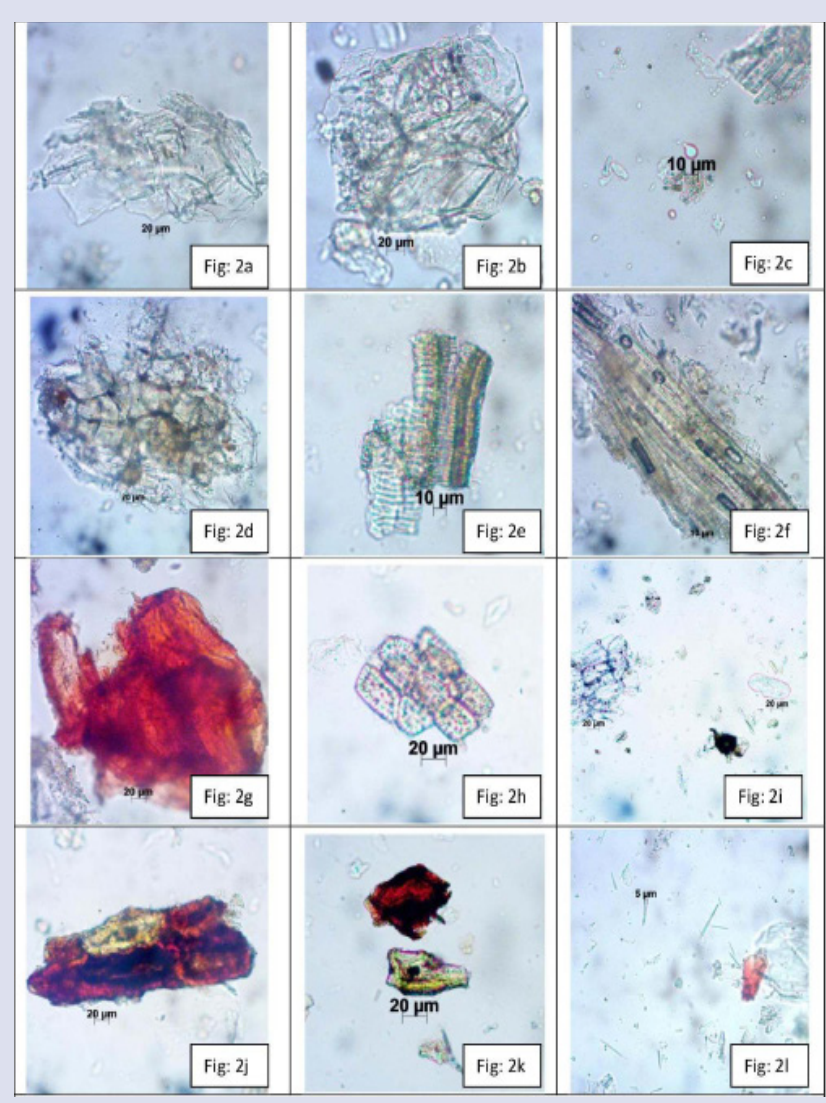

Figure 2: Powder Microscopy of Rhizome of Chlorophytum borivilianum Sant. and F.

Fig: 2a - Parenchyma with starch grains; Fig: $2 \mathrm{~b}$ - Parenchyma with bunch of starch grains; Fig: 2c - Isolated starch: Fig: $2 d$ - Fragments of Epiblema: Fig: 2e - Vessels; Fig: $2 \mathrm{f}$ - Bundle of fibres; Fig: $2 \mathrm{~g}$ - Cork cells; Fig: $2 \mathrm{~h}$ - Group of Stone cells: Fig: $2 \mathrm{i}$ - Pitted xylem parenchyma; Fig: $2 \mathrm{j}$ Group of Sclereids; Fig: 2k - Isolated sclereids; Fig: 21 - Aciculur needles,

Table 2: Physico-chemical Evaluation of Rhizome of Chlorophytum borivilianum Sant. and F.

\begin{tabular}{ll} 
Observations & Observed values \\
Foreign matter & $7.93 \pm 0.06 \%$ \\
Loss on drying & $8.70 \pm 0.02 \%$ \\
Total ash & $8.91 \pm 0.05 \%$ \\
Acid insoluble ash & $4.51 \pm 0.01 \%$ \\
Water soluble ash value & $06.45 \pm 0.02 \%$ \\
Alcohol soluble extractive & $3.97 \pm 0.04 \%$ \\
Water soluble extractive & $24.78 \pm 0.11 \%$ \\
\hline
\end{tabular}

\section{Phytochemical Evaluation}

Phytochemical evaluation of Chlorophytum borivilianum Sant. and F. revealed the presence of alkaloid, carbohydrate, carboxylic acid, resins and saponins in the rhizome. Detail of phyto-chemical evaluation is illustrated in Table 3.

\section{HPTLC Finger printing}

$\mathrm{R}_{\mathrm{f}}$ values and color of the spots in chromatogram developed in toluene: ethyl acetate (7.0:3.0) for ethanolic extract of rhizomes of Chlorophytum borivilianum Sant. and F. were recorded. The details of $R f$ value is given in Table 4. TLC photo-documentation revealed presence of many phytoconstituents with different $R f$ values and HPTLC densitometric scan of the plates showed numerous bands under short UV, long UV and 620 $\mathrm{nm}$ (after derivatisation).

\section{PHOTO DOCUMENTATION (SOLVENT SYSTEM PET ETHER: ETHER ACETATE)}

Two spots were detected under short UV - $254 \mathrm{~nm}$ in Chlorophytum borivilianum Sant. and F. ( $R f 0.70,0.77)$. All of them were having light green color. Four spots were detected under long UV - $366 \mathrm{~nm}$ ( Rf 0.04, 0.38 - fluorescent light blue color, $R f$ 0.72, 0.84 - fluorescent dark blue color). Three spots were detected after derivatisation - $620 \mathrm{~nm}$ (Rf 0.24, 0.54, 0.77 - light purple color). Detail of HPTLC photo documentation are illustrated in Figure 3.

\section{HPTLC DENSITOMETRIC SCAN}

Total 17 numbers of active components were detected in Chlorophytum borivilianum Sant. and F. having $R f$ value $(0.01,0.04,0.25,0.27,0.33,0.39$, $0.60,0.79,0.85,0.05,0.42,0.79,0.03,0.21,0.28,0.56,0.68,0.86)$. The detail of HPTLC photo documentation are illustrated in Figure 4. Nine peaks were detected under short UV - $254 \mathrm{~nm}$; among them maximum percentage of area were occupied by $R f 0.01$ (35.26\%), 0.04 (12.94\%), $0.33(11.11 \%)$. Four peaks were detected under long UV - 366nm; among them maximum percentage of area were occupied by $R f 0.01(67.65 \%)$, 0.05 (21.20\%), 0.79 (7.54\%). Six peaks were detected after derivatization - $620 \mathrm{~nm}$; among them maximum percentage of area were occupied by $R f$ 0.03 (65.06\%), 0.68 (13.38\%), 0.86 (9.51\%).

\section{DISCUSSION}

\section{Macroscopic characters}

Rhizome of C. borivilianum was elongated, with whitish external surface. It was smooth and having horizontal wrinkles on drying. It was not having any characteristics odor. It was having Madhura (Sweet), Tikta (Bitter) and mucilaginous taste. Powder of C. borivilianum was brownish in color.

\section{Microscopic characters}

Transverse section of rhizome of C. borivilianum was having epidermis, cork, starch grains, idioblast cells, outer cortex, xylem, phloem, radial vascular bundle, collenchyma cells, single layered endodermis, stellar region, pith, and numerous cluster crystals. Powder microscopy of the given sample had pitted xylem parenchyma, starch grains, cork cells, sclereids, bundle of fibers, vessels, acicular needles, fragments of epiblema and stone cells.

Relevance of finding from current study related to microscopic evaluation can be also substantiated from the earlier works. ${ }^{23}$

\section{Phytochemical Analysis}

Phytochemical analysis of Chlorophytum borivilianum Sant. and F. had shown presence of alkaloid, carbohydrate, carboxylic acid, resins and saponins. Previous studies had shown presence of steroid, glycosides, saponins, and triterpenoid starch in Chlorophytum borivilianum Sant. and $\mathrm{F}^{23-24}$

\section{TLC AND HPTLC}

$\mathrm{R}_{\mathrm{f}}$ values and color of the spots in chromatogram developed in toluene: ethyl acetate (7.0:3.0) for ethanolic extract of rhizomes of Chlorophytum borivilianum Sant. and F. were recorded. TLC photo-documentation revealed presence of many phytoconstituents with different $R f$ values and HPTLC densitometric scan of the plates showed numerous bands under short UV, long UV and $620 \mathrm{~nm}$ (after derivatisation). 
Table 3: Phytochemical evaluation of Chlorophytum borivilianum Sant. and $F$.

\begin{tabular}{|c|c|c|c|c|}
\hline & Test & Color if positive & Result & Remarks \\
\hline \multirow[t]{4}{*}{1.} & Alkaloids & & & \\
\hline & Dragendrof's test & Orange precipitate & Orange precipitate & Present \\
\hline & Wagners test & Red precipitate & Red precipitate & Present \\
\hline & Mayers test & $\begin{array}{l}\text { Dull white } \\
\text { precipitate }\end{array}$ & $\begin{array}{l}\text { Dull white } \\
\text { precipitate }\end{array}$ & Present \\
\hline \multirow[t]{3}{*}{2.} & Steroids & & & \\
\hline & $\begin{array}{l}\text { Liebermann- } \\
\text { buchard test }\end{array}$ & Bluish green & No Bluish green & Absent \\
\hline & Salkowski test & $\begin{array}{l}\text { Bluish red to cherry } \\
\text { red }\end{array}$ & $\begin{array}{l}\text { Red color in the } \\
\text { chloroform }\end{array}$ & Absent \\
\hline \multirow[t]{4}{*}{3.} & Carbohydrate & & & \\
\hline & Molish test & Violet ring & Violet ring & Present \\
\hline & Fehlings test & Brick red precipitate & Bluish color & Absent \\
\hline & Benedicts test & Red precipitate & Bluish color & Absent \\
\hline \multirow[t]{2}{*}{4.} & Tannin & & & \\
\hline & With $\mathrm{FeCl}_{3}$ & $\begin{array}{l}\text { Dark blue or green } \\
\text { or brown }\end{array}$ & Golden Yellow Color & Absent \\
\hline \multirow[t]{2}{*}{5.} & Flavanoids & & & \\
\hline & $\begin{array}{l}\text { Shinoda's test } \\
\text { Saponins }\end{array}$ & Red to pink & Golden Yellow Color & Absent \\
\hline 6. & $\begin{array}{l}\text { With } \mathrm{NaHCO}_{3} \\
\text { Triterpenoids }\end{array}$ & Stable froth & Stable froth & Present \\
\hline 7. & $\begin{array}{l}\text { Tin and thionyl } \\
\text { chloride test }\end{array}$ & Red & Black color & Absent \\
\hline \multirow[t]{2}{*}{8.} & Coumarins & & & \\
\hline & With $2 \mathrm{~N} \mathrm{NaOH}$ & Yellow & Colorless solution & Absent \\
\hline \multirow[t]{2}{*}{9.} & Phenols & & & \\
\hline & $\begin{array}{l}\text { With alcoholic } \\
\text { ferric chloride }\end{array}$ & $\begin{array}{l}\text { Blue to blue black, } \\
\text { brown }\end{array}$ & $\begin{array}{l}\text { Golden Color } \\
\text { solution }\end{array}$ & Absent \\
\hline \multirow[t]{2}{*}{10.} & Carboxylic acid & & & \\
\hline & $\begin{array}{l}\text { With water and } \\
\mathrm{NaHCO}_{3}\end{array}$ & Brisk effervescence & Brisk Effervescence & Present \\
\hline \multirow[t]{2}{*}{11.} & Resin & & & \\
\hline & $\begin{array}{l}\text { With aqueous } \\
\text { acetone }\end{array}$ & Turbidity & Turbidity & Present \\
\hline \multirow[t]{2}{*}{12.} & Quinone & & & \\
\hline & $\begin{array}{l}5 \% \mathrm{NaOH} \\
\text { Amino acids }\end{array}$ & Pink/purple/red & Color less solution & Absent \\
\hline 13. & $\begin{array}{l}\text { Ninhydrine } \\
\text { reagent }\end{array}$ & Purple color & Color less solution & Absent \\
\hline
\end{tabular}

\section{Photo documentation (solvent system pet ether: ether acetate)}

Total eight spots detected in Chlorophytum borivilianum Sant. and F in different Rf value. Number of spots indicates the total number of active chemical components present in the given sample.

\section{HPTLC Densitometric scan}

Total 17 numbers of active components were detected in Chlorophytum borivilianum Sant. and F. having $\mathrm{Rf}$ value $(0.01,0.04,0.25,0.27,0.33$, $0.39,0.60,0.79,0.85,0.05,0.42,0.79,0.03,0.21,0.28,0.56,0.68,0.86$ )
Table 4: $\boldsymbol{R f}$ values of Ethanolic Extract of Rhizome of Chlorophytum borivilianum Sant. and F.

\begin{tabular}{lll}
\hline Short UV & Long UV & After derivatisation \\
\hline- & 0.04 (FL. blue) & - \\
- & - & 0.24 (L. purple) \\
- & - & - \\
- & - & - \\
- & 0.38 (FL. blue) & - \\
- & - & - \\
- & - & - \\
- & - & 0.59 (L. purple) \\
- & - & - \\
0.70 (L. green) & - & - \\
- & 0.72 (FD. blue) & - \\
0.77 (L. green) & - & 0.77 (L. purple) \\
- & 0.84 (FD. blue) & - \\
D-Dark; L-Light; F- & & \\
Fluorescent & &
\end{tabular}

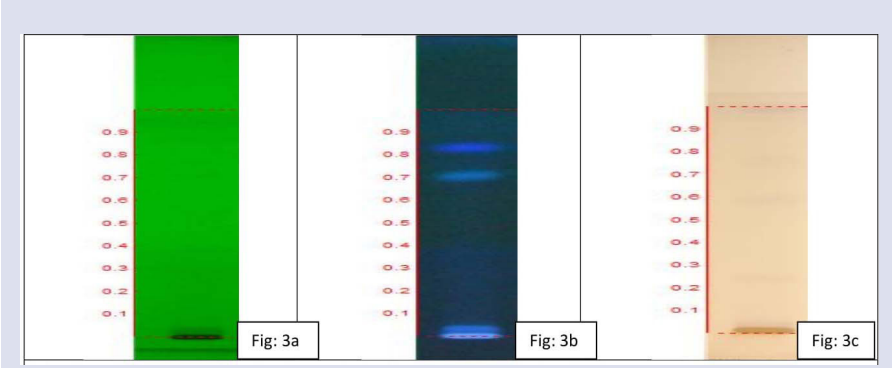

Figure 3: HPTLC Photo Documentation of Rhizome of Chlorophytum borivilianum Sant. and F.

among them maximum percentage of area were occupied by Rf 0.01 (35.26\% - 254nm); 0.01 (67.65\% - 366nm), 0.03 (65.06\% - 620nm). Relevance of finding from current study related to HPTLC fingerprinting can be also substantiated from the earlier works. ${ }^{23}$

\section{CONCLUSION}

Macro-microscopic, physico-chemical, preliminary phytochemical and HPTLC finger printing of Chlorophytum borivilianum Sant. and F. has been carried out as per pharmacopoeial methodology. The detail presented in the study shows the qualitative presence of various secondary metabolites and in the rhizome of Chlorophytum borivilianum Sant. and F. Thus, the study was helpful in the qualitative analysis of genuinity of the given drug.

\section{ACKNOWLEDGEMENT}

Authors are highly grateful to Department of Dravyaguna, SDM College of Ayurveda, Hassan; SDM Center for Research in Ayurveda and Allied science, Udupi for providing the lab facilities.

\section{CONFLICT OF INTEREST}

The authors declare no conflict of interest.

\section{ABBREVIATIONS}

TLC: Thin layer chromatography; HPTLC: High Performance Thin layer chromatography; $\boldsymbol{R} f$ : Retention factor; UV: Ultra violet; $\mathbf{n m : ~ N a n o}$ meter; ml: Mili-liter; $\mu$ l: Micro-liter; viz: Namely. 


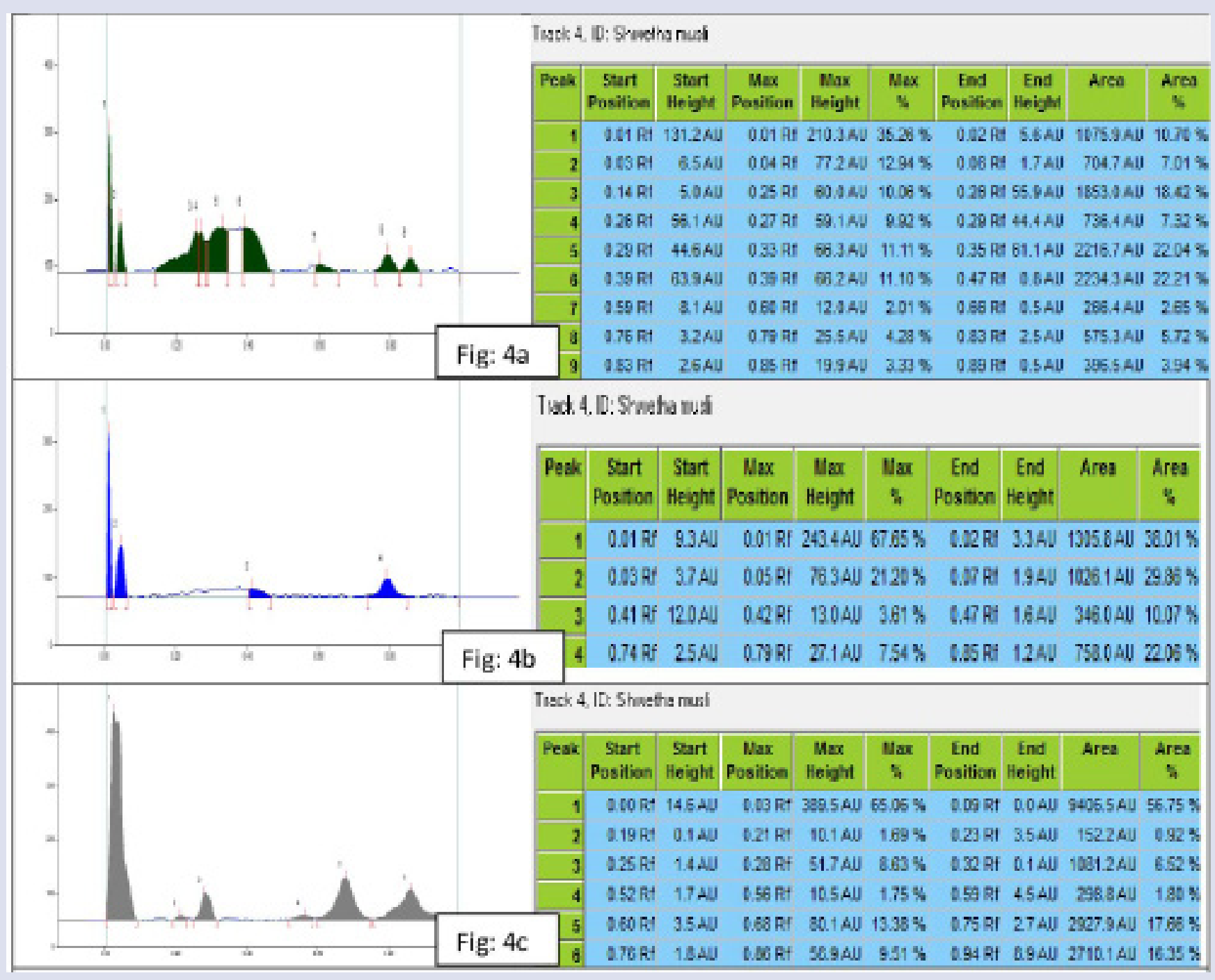

Figure 4: Densitometric scan of Rhizome of Chlorophytum borivilianum Sant. and F.

\section{REFERENCES}

1. Patil VN, Deokule SS. Pharmacognostic evaluation of Chlorophytum orchidastrum Lindl. Annals of Biological Research. 2010;1(4):126-37.

2. Sharma R, et al. Saponin: A wonder drug from Chlorophytum species. Global Journal of Research on Medicinal Plants and Indigenous Medicine. 2012;1(10):503-15

3. Thakur GS, Bag M, Sanodiya BS. Debnath M, Bhadouriya P, Prasad GBKS, et al. Chlorophytum borivilianum A white gold for biopharmaceuticals and Neutraceuticals. Current Pharmaceutical Biotechnology. 2009;10(7):650-66.

4. Sri Bhava Misra. Bhavprakash Nighantu, Guduchyadi Varga, edited by Misra Brahmasankara, Vaisya Rupalal, part 1, Chaukhamba Sanskrit Samsthana, Varanasi, 1999;389-91.

5. Singh A, Khanuja SPS, Singh S. Agronomic practices for the production of Safed musli (Chlorophytum borivilianum Sant. and F.) in India. Natural Product Radiance. 2000;2(6):308-13.

6. Mandal DG, Nandi AK. Morphological and anatomical circumscription for the identification of two source of aphrodisiac medicine Chlorophytum borivilianum Sant. and F. and Chlorophytum tuberosum (Roxb.) Baker. International Journal of Medicinal and Aromatic Plants. 2012;2(3):406-10.

7. Sharma R. Agro-Techniques of Medicinal Plants. Daya Publishing House, Delhi. 2004;168.

8. Joshi, Joshi, Prajapati. Seed album of Some Medicinal Plants of India. Asian Medicinal Plants and Health Care Trust, Jodhpur (Rajasthan) India. 2005;16.

9. Pandit Narahari. Raj Nighantu, Mulakadi Varga, 115-7, translated by Tripathi In- dradeva. Krisnadasa Academy, Varanasi, 1982; 208-209.

10. Gupta AK, Madhu S. Reviews on Indian medicinal plants, vol.6. Medicinal plants unit, Indian council of medical research; New Delhi, India, 2008;87-90.

11. Kenjale R, Shah R, Sathaye S. Effects of Chlorophytum borivilianum on sexual behavior and sperm count in male rats. Phytotherapy Research. 2008;22(6):796-801.

12. Mohd M, Shah AK, Mohd A, Abhishek M, Aftab A. Antidiabetic activity of the aqueous extract of Chlorophytum borivilianum in Streptozotocin inducedhyperglycemic rats- A preliminary study. Journal of Pharmacy Research. 2009;2(1):51-3.

13. Kenjale RD, Shah RK, Sathaye SS. Anti-stress and anti-oxidant effects of roots of Chlorophytum borivilianum Sant. and F. Indian Journal of Experimental Biology. 2007:45:974-9.

14. Sundaram S, Dwivedi P, Purwar S. Antibacterial activities of crude extracts of Chlorophytm borivilianum to bacterial pathogens. Research Journal of Medicinal Plants. 2011;5(3):343-7.

15. Sreevidya N, Govindarajan R, Vijayakumar M, thakur M, Dixit VK, Mehrotra S, Madhusudan KP. Action of fructo-oligo polysaccharide fraction of Chlorophytum borivilianum against streptozotocin induced oxidative stress. Planta Medica. 2006;72(15):1421-4.

16. Acharya D, Mitaine-Offer AC, Kaushik N, Miyamoto T, Paululat T, MirjoletT, et al. Steroidal Saponin from Chlorophytum borivilianum. Journal of Natural Products. 2009;73:7-11.

17. Kokate CK. Practical pharmacognosy. Vallabh Prakasan, New Delhi. 1986;111.

18. Johansen DA. Plant microtechnique. Mc Graw-Hill Book Company, Inc: London. 1940:530. 
19. Berlyn GP, Mikcsche JP, Sass JE. Botanical microtechnique and cytochemistry. lowa State University Press. 1976.

20. Khandelwal KR. Practical Pharmacognosy Techniques and Experiments. Nirala Prakashana. 20 ${ }^{\text {th }}$ ed.2010;23.1-23.7.

21. Stahl I. Thin layer chromatography. A laboratory Hand Book (Student edition), Berlin, Springer-Verlag. 1969;52-86.

22. Sethi PD. High performance thin layer chromatography. $1^{\text {st }}$ ed. New Delhi, CBS
Publishers and Distributors; 1996.

23. Nandi et al. Comparative pharmacognostic and phytochemical studies of two aphrodisiac plants Chlorophytum borivilianum Santapau and Fernandes and Chlorophytum tuberosum (Roxb.) Baker. International Journal of Pharmacy and Pharmaceutical Science. 2013;5(4):517-23.

24. Panda SK, Das D, Tripathy NK. Pharmacognostical Studies on Root Tubers of Chlorophytum borivilianum Santapau and Fernandes. International Journal of Pharmaceutical and Phytochemical Research. 2010;2(4):13-7.

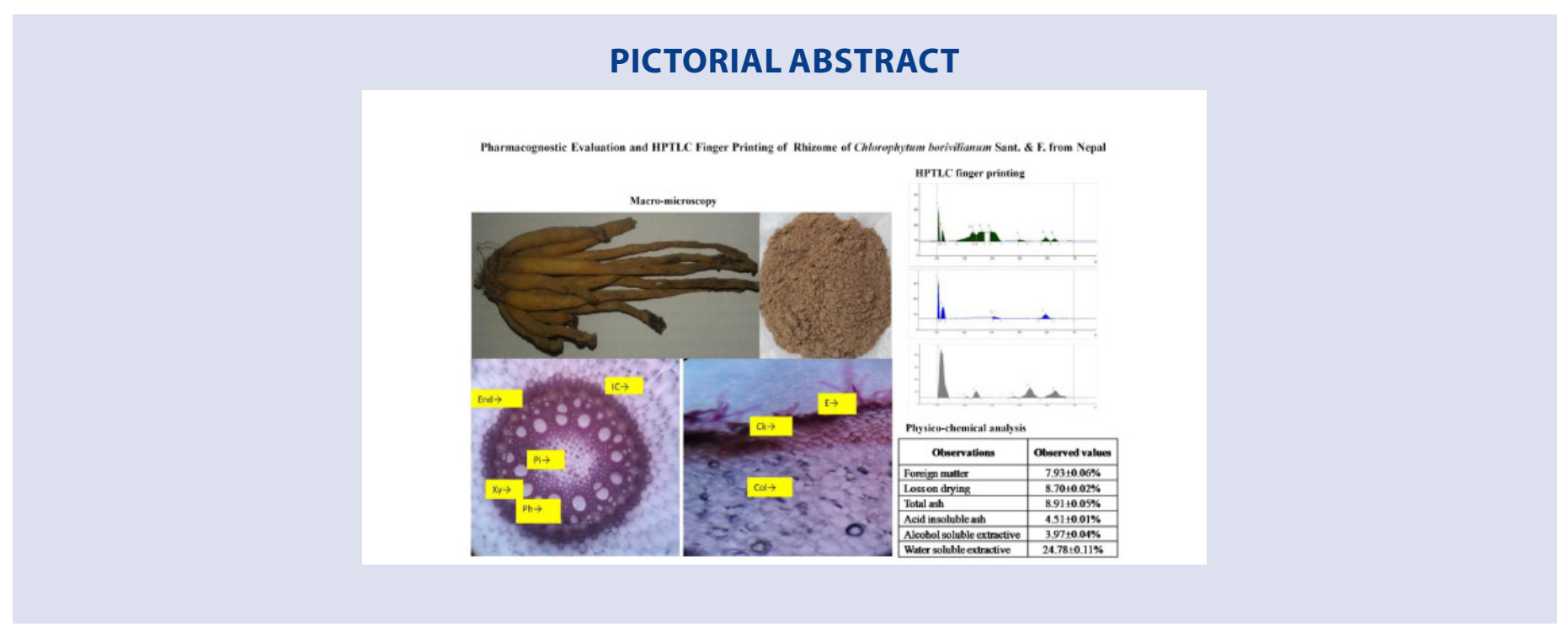

Cite this article: Kopila A, Anuradha KN, Prabhu Suchitra N. Pharmacognostic Evaluation and HPTLC Finger Printing of Rhizome of Chlorophytum borivilianum Sant. and F. from Nepal. Pharmacogn J. 2018;10(5):963-8. 